\title{
The 2015 Portuguese Legislative Election: Widening the Coalitional Space and Bringing the Extreme Left in
}

\section{Elisabetta De Giorgi \& José Santana-Pereira}

To cite this article: Elisabetta De Giorgi \& José Santana-Pereira (2016): The 2015 Portuguese Legislative Election: Widening the Coalitional Space and Bringing the Extreme Left in, South European Society and Politics

To link to this article: $h$ ttp://dx.doi.org/10.1080/13608746.2016.1181862

Published online: 12 May 2016.

Submit your article to this journal $\pi$

Lll Article views: 85

View related articles

View Crossmark data $\asymp$ 


\title{
The 2015 Portuguese Legislative Election: Widening the Coalitional Space and Bringing the Extreme Left in
}

\author{
Elisabetta De Giorgi and José Santana-Pereira
}

\begin{abstract}
This article provides an overview of the Portuguese legislative election held on 4 October 2015 by exploring the economic and political context in which the election took place, the opinion polls, party positions and campaign issues, the results and, finally, the process that led to the formation of the first Socialist minority government supported by far-left parties. Due to this outcome, despite the relative majority of the votes obtained by the incumbent centre-right coalition, we argue that this election result cannot be interpreted as a victory of austerity, but rather as the first step towards contract parliamentarism in Portugal.
\end{abstract}

KEYWORDS

Portugal; António Costa; BE; PCP; PS

The 2015 legislative election constituted a second test of the resilience of the Portuguese party system in a context of severe economic crisis, following that of the 2011 election, which had resulted in few changes in its format and a severe defeat for the incumbent Partido Socialista (Socialist Party - PS). ${ }^{1}$ Contrary to what happened in Greece, Italy and Spain, the incumbent defeat was not accompanied by a significant reduction in the electoral weight of the traditional parties or the surge of new, anti-establishment parties (Freire \& Santana-Pereira 2012; Magalhães 2012; Martín \& Urquizu-Sancho 2012; Borghetto, De Giorgi \& Lisi 2014; Tsatsanis \& Teperoglou 2014). This exceptionality of the Portuguese party system was maintained in the following years: in fact, the balance between the two mainstream parties and their smaller counterparts remained quite stable in the 2013 local and 2014 European elections, despite a trend of lower vote shares for the two main parties taken as a whole vis-à-vis 2011, which is typical of second-order elections. The Portuguese party system seemed, in both first- and second-order elections taking place during the years of austerity, to be as solid as a rock.

As a consequence, in 2015 no one expected the disappearance of the traditional parties or the rise of new strong anti-establishment actors: the question was rather whether the main challenger would be able to outdo the incumbent coalition at the polls and secure the right to govern. On 4 October 2015 it became clear that this was not the case, since the incumbent right-wing coalition - composed of the Partido Social Democrata (Social Democratic Party - PSD) and the Centro Democrático e Social-Partido Popular (Democratic and Social Centre-People's Party - CDS-PP) - was the most voted-for political force and the Socialists secured a disappointing 32 per cent of the vote share. 
Many foreign newspapers chose to report the election result as 'Portugal's austerity government wins re-election,' ${ }^{2}$ highlighting above all the electorate's endorsement of the incumbent government at a time when governing parties were facing a popularity crisis all over Southern Europe. The situation was far more complex than that, though. While it was true that the parties that had implemented the adjustment programme from 2011 onwards obtained the relative majority of votes, austerity cannot be said to have won the election. Indeed, many features suggest quite the opposite. To begin with, the so called 'anti-austerity' parties in parliament - i.e. Bloco de Esquerda (Left Bloc - BE) and Partido Comunista Português (Portuguese Communist Party - PCP) in coalition with Partido Ecologista 'Os Verdes' (The Greens - PEV) - obtained 18 per cent of the votes. The BE, in particular, doubled its 2011 result. Also, the governing coalition Portugal à Frente (Portugal Ahead - PAF) lost 12 percentage points vis-à-vis its 2011 result. Moreover, the sum of the votes obtained by the three parties that had alternated in government in the preceding decades (the PS, PSD and CDS-PP) was the lowest since 1985. Lastly, the election results led to a government headed by the main opposition party (the PS) with the support of the far left ${ }^{3}$ for the first time in the history of democratic Portugal.

This article attempts to provide an overview of the most recent legislative election in Portugal, including the process that led to the formation of a minority PS government in late November 2015, and offers tentative answers to some of the questions that arose both before and after the election. How did the incumbents during one of the worst periods of recession in recent Portuguese history manage to secure the voters' confidence and obtain a relative majority in this election? Why did no new strong political challenger appear on the scene as happened in other Southern European countries after 2008?

The article is divided into five sections. The first introduces the economic and political context in which the election took place, and is followed by the presentation of the main political players in this electoral contest. The opinion polls and leader performance assessments, party positions and campaign issues are discussed in the following section. After that, we present and examine the election results. The last section outlines one of the longest processes of government formation in Portuguese history and its final outcome. The article ends with some concluding notes on the nature and impact of the 2015 legislative election in Portugal.

\section{The economic and political context: a visit from the troika and its mementos (2011-15)}

After the outbreak of the global financial crisis, the Portuguese economy shrunk by nine per cent between 2008 and 2013 and unemployment, which had already risen from 6.2 to 8.8 per cent in the 2002-08 period, continued to grow, reaching a peak of 16.4 per cent in 2013. The second Socialist government led by José Sócrates (in office since 2005) initially managed to approve the austerity packages required by the European Union (EU), thanks to the PSD's cooperation, but had to resign after the rejection of an additional package in parliament (March 2011). A bailout was then requested and a memorandum of understanding (MoU) was signed in May by the lenders - the European Commission, the European Central Bank (ECB) and the International Monetary Fund (known as the 'troika') - and three parties (PS, PSD and CDS-PP). This would mean that, no matter which party won the successive election, the new executive would be constrained by the commitments to the international lenders 
(De Giorgi, Moury \& Ruivo 2015), as in Ireland (Mair 2011). By contrast, the radical parties (PCP, PEV and BE) considered the bailout antidemocratic and unnecessary and refused to participate in the talks with the troika. In June the centre-right PSD won the legislative election but, to secure a majority of members of parliament, had to form a post-electoral coalition with the right-wing CDS-PP (Magalhães 2012).

Thereafter, the Passos Coelho cabinet put its heart and soul into the approval of austerity measures considered essential for the success of the adjustment programme and the economic recovery plan. In this regard, two contradictory narratives coexist: some observers argue that, since the beginning of the crisis, governments have been forced to implement unpopular reforms in exchange for bailout loans (Ladi 2014) or because of implicit warnings by the supranational institutions (Sacchi 2015); others claim that the crisis empowered governments to pass reforms they had sponsored all along (Moury \& Freire 2013). Left-wing parties such as BE and PCP accused the executive of Passos Coelho of the latter from the start of its mandate, while the PS subsequently echoed this sentiment although it had signed the bailout together with the two right-wing parties.

Portugal ended its adjustment programme in May 2014 and, like Ireland and unlike Greece, did not need a second bailout. The official economic accounts for 2014 showed that the economy displayed signs of recovery: for the first time since 2011 gross domestic product (GDP) growth rate was positive (albeit weak: 0.9 per cent), and the unemployment rate fell from 16.4 to 13.3 per cent. ${ }^{4}$ Moreover, while most citizens described the country's economic situation as bad, the proportion believing that the situation would improve in the following year rose from four per cent in November 2011 to 27 per cent in May 2015. ${ }^{5}$

The four years following the 2011 legislative election were far from tranquil. The PS started by adopting a cooperative stance towards the government, contributing to the approval of its most relevant measures and voting against the motions of censure presented by the PCP and BE. Its voting behaviour was actually irrelevant to the safe passage of the government's legislation, as the centre-right executive had an absolute majority, so its conduct was even more significant and certainly owed to a sense of responsibility towards the supranational actors involved in the bailout. In contrast, BE, PCP and PEV sustained their highly conflictual behaviour towards the government, proving once again the difference between mainstream and extreme parties in opposition, even in times of crisis (De Giorgi \& Moury 2015). However, in late 2012, the PS voted against both a second amendment to the 2012 budget and the 2013 budget and thereafter started to align in parliament with the other left-wing parties (De Giorgi, Moury \& Ruivo 2015), voting against critical and highly politicised bills. Furthermore, the PS requested a review of the constitutionality of some austerity laws approved by the centre-right majority and, on key issues, the Constitutional Court ruled in their favour, thus pushing the government to find alternative measures under the pressure of the international lenders.

Two second-order elections took place during the 2011-15 legislature. The PS managed to win both the 2013 local elections (Jalali 2014) and the 2014 European election (Freire \& Santana-Pereira 2015). In the latter, the governing parties obtained a very poor result (27.7 per cent): 22 percentage points less than their combined 2011 vote shares (50.4 per cent) and 12 percentage points less than their joint results in the 2009 European Parliament (EP) election. The PS result was also disappointing, as its electoral growth vis-à-vis 2009 and 2011 was feeble (26.5 per cent in 2009; 28.1 per cent in 2011, 31.5 per cent in 2014). In similar circumstances (2004), the PS had been able to win the European election by a landslide (Freire \& Santana-Pereira 2015). This meagre Socialist victory was widely discussed in the 
public arena, led to internal turmoil and was one of the reasons behind the replacement of the party leader the following autumn.

In late 2014, Portuguese politics was shaken by two major scandals that hit both the PSD and the PS. The first related to suspicions of corruption in the government's so-called 'golden visa' programme and resulted in the Minister of the Interior's resignation. The Portuguese authorities had issued 1,775 visas to offer residence permits to wealthy non-Europeans (mainly Chinese) who wanted to invest in the country. Irregularities regarding the way these visa were being granted led to the detention of 11 people administering the scheme. Portugal was still reeling from this event when a new scandal rocked the country. The former prime minister (PM), Sócrates, was arrested on 22 November on suspicion of corruption, tax fraud and money-laundering. After an initial hearing, the judge decided there was sufficient evidence to keep Sócrates in custody. The newly elected party leader, António Costa, found himself in a very delicate situation, since he was not only a former minister in the first Sócrates cabinet but also a friend of the ex-PM.

Meanwhile, political institutions such as the national government, parliament and political parties were the object of increasing distrust among Portuguese citizens (Teixeira, Tsatsanis \& Belchior 2014). Nevertheless, as noted previously, neither this nor the above-mentioned economic and political developments generated any new political challengers to the traditional parties. What may have played a role in this was the presence in parliament of well-established far-left parties that seemed able to channel the electorate's sentiments of protest and discontent in recent years, never losing ground to the new forms of political action, such as the social movements involved in organising the main demonstrations between 2011 and 2013, and even shrewdly trying to gain popularity through them (Accornero \& Pinto 2015). In fact, the presence of these parties left little political space for a further leftwing competitor. Unlike in countries like Spain, the anti-austerity mobilisations in Portugal continued to be led by traditional actors - i.e. unions and left-wing parties (Accornero \& Pinto 2015) - despite the presence of new movements such as the Geração à Rasca (Desperate Generation) and Que Se Lixe a Troika (Screw the Troika), composed largely of young people but unable (or unwilling) to form a new political force challenging the existing parties (Baumgarten 2013). Even the BE, which has often been compared to new forces such as Podemos in Spain (and actually shares with them many programmatic statements), can hardly be considered as a new challenger, since it has been in parliament since 1999.

Furthermore, unlike Greece, Italy and Spain, Portugal lacked a true'protest entrepreneur' at the head of the anti-austerity and anti-party mobilisations, able to lead the challenge to the traditional party system. Finally, despite the increase in public demonstrations since the beginning of the recession, Portuguese citizens have a very low level of trust in the efficacy of political participation (Baumgarten 2013) and the levels of political engagement in Portugal are far from those of other Southern European countries. As asserted by Afonso (2015), we may then assume that disappointed but politically engaged citizens will choose challenger parties that give voice to their protest, while disappointed but disaffected citizens will rather choose not to turn out to vote, that is, a disengagement strategy. The latter seems to have prevailed in Portugal, as we will see in the following sections.

\section{The same old and a few new ones? The protagonists of the 2015 election}

Portugal has been a relatively stable multi-party system since the first legislative election in 1976. The core of the Portuguese party system is constituted by the CDS-PP, PCP, PS and PSD, 
which have been around since (at least) 1974, but also BE, which was able to enter parliament in 1999. The entry of new parties into parliament is very rare, and has never taken place in the twenty-first century. The effective number of parties in parliament has always remained relatively low and the two larger parties - the PS and the PSD - have alternated in the roles of (main) incumbent and main opposition party. Despite having considerable parliamentary representation, both the Communists and the BE were outside the arco da governação (arc of government, that is, the group of parties that had governmental experience and/or were willing to take governmental responsibilities) throughout the course of Portuguese democratic history.

Three different types of political forces participated in the 2015 legislative election: four parties or coalitions that already had parliamentary representation; three new/small parties that were seen as having a chance of electing a member of parliament (MP) due to their performance in the 2014 EP election (Freire \& Santana-Pereira 2015); and several microparties with little prospect of entering the parliamentary arena. The traditional parties with parliamentary representation are the governing coalition PAF, their main opponent and competitor PS, the far-left BE and the communist/green coalition Coligação Democrática Unitária (Unitary Democratic Coalition - CDU).

As already noted, this had been a difficult term for the incumbents, as they had been forced to take unpopular decisions. The PSD popularity had started falling in November 2011 and, one year later, the polls put the PS in the lead (De Giorgi, Moury \& Ruivo 2015). The major accusation against the incumbent was that they had broken promises made to Portuguese citizens in an unprecedented way (Freire 2015).

The situation caused serious frictions even within the governing coalition, the CDS-PP leader and Minister of Foreign Affairs, Paulo Portas, periodically showing his disagreement with Passos Coelho's and the Finance Minister's strong commitment to austerity. Two difficult moments experienced by the coalition stand out. The first, in 2012, followed the announcement of an increase in the social security contribution paid by workers to offset a reduction in the employers' contribution. The decision (subsequently revoked) generated one of the biggest mobilisations ever seen in Portugal (Accornero \& Pinto 2015).

But the most critical moment came in July 2013. Following the Finance Minister's resignation, Portas unexpectedly announced he would be leaving the government because he believed the new minister represented continuity in government policies rather than the change he wanted. The country waited with bated breath for the outcome of this extreme action, but in a televised address Passos Coelho said that he would work for a rapid return to stability. Indeed, Portas and his party did not leave the coalition, the government managed to survive and the two parties actually started the long (sometimes challenging) road towards consolidating their alliance, ultimately forming a pre-electoral coalition in both the 2014 EP election and the 2015 legislative election. This decision was taken in order to minimise electoral losses due to their role as incumbents during the implementation of a financial adjustment programme, since the Portuguese electoral system tends to favour larger parties and coalitions (Lijphart 2012). Furthermore, it may be read as a (successful) attempt of the governing parties to come out ahead of the PS, which was running as a lone party: a result that might have been more difficult for the PSD to achieve alone if the two parties had run separately, as they usually did.

As for their main opponent and competitor, José Sócrates led the PS until the electoral defeat of 5 June 2011. He was then replaced by António José Seguro at the extraordinary 
party congress in July 2011. However, Seguro's leadership was questioned after the unsatisfactory result of the PS in the 2014 European election and, just two days later, he was officially challenged by the Mayor of Lisbon, António Costa. On September 28, for the first time in its history the PS held primary elections in order to select its PM candidate in the upcoming elections. Costa obtained a clear victory, receiving 67.7 per cent of votes, and became the new PS secretary general two months later.

Seguro had already been criticised for being too soft and ineffective in opposition, although criticisms had apparently more to do with his style than with the party's actual behaviour under his leadership. In fact, legislative data show that the PS was less likely to vote against the government than the other left-wing opposition parties but opposed the executive more than the PSD did in the previous legislature (2009-11), when the PS was the incumbent and the latter the main opposition party. In fact, the PS voted against the government about 40 per cent of the time in the period 2011-14 (De Giorgi \& Russo 2015), while the PSD had opposed the initiatives of the second Sócrates cabinet only about ten per cent of the time.

Turning to the far-left parties: the last four years were the most troubled in the short life of the BE (founded in 1999). After the historical result of 2009 (16 MPs elected), the 2011 election was a disaster for the party, which secured only eight parliamentary seats. The party leader resigned one year later and was succeeded by a co-leadership. But this bicephalous model was not very popular and the party's situation was further complicated when the BE lost electoral support in the local (2013) and European elections (2014). In November 2014, a new six-member leadership board was approved with Catarina Martins as the party spokesperson. The charismatic Martins - a 42-year-old actress, elected in 2009 as BE MP in the Oporto district - was able to heal some of the internal conflicts thanks to a strong political vision. The BE obtained noteworthy results in parliament, such as a successful request for the review of the constitutionality of some government proposals; its image also benefited from the parliamentary performance of figures such as the MP Mariana Mortágua, who obtained great visibility after her performance at the parliamentary inquiry following the collapse of Banco Espírito Santo, one of the country's largest banks. Furthermore, the BE engaged in the protests against austerity, the troika and the government; it was always present in the most visible demonstrations, general strikes and union struggles. In short, the BE was on the street and in parliament.

The Communists' road was far less rocky. The PCP was the harshest opponent of the government's policies following the signature of the memorandum (which the party leader, Jerónimo de Sousa, defined as an 'act of aggression ${ }^{6}{ }^{6}$ and it was this that determined its strategy over the last four years. The party refused to have dialogue with the troika and presented three motions of censure to the government in four years. Its strategy was also to attack the PS, seen as sharing responsibility with the government for the bailout and the troika's presence in the country. Despite a fairly old-school traditional ideological discourse, the PCP is a very well-organised party and has a stable electorate. The CDU, a stable electoral alliance between the Communists and the Greens, increased the number of municipalities under its rule in the 2013 local election, and elected three members of the EP (MEPs) in 2014, one more than in the 1999-2014 period (Freire \& Santana-Pereira 2015).

To conclude, we should say that these far-left parties were the only ones that clearly opposed austerity and put forward alternative solutions (such as debt renegotiation) in parliament from the signature of the memorandum to the very last day of the campaign. 
Moreover, as they have been in parliament for a long time, they have a higher level of legitimacy in the eyes of the Portuguese electorate vis-à-vis new or smaller left-wing parties adopting the same discourse.

A few notes should also be added regarding three extra parliamentary parties. First, LivreTempo de Avançar (Free-Time to Move Forward - L-TDA) was created just before the 2014 EP election. The party secured 2.2 per cent of the votes in May 2014, which was not enough to elect an MEP; however, if these results were to be repeated in 2015, they could lead to the election of an MP in large electoral districts like Lisbon or Oporto. L-TDA is a radical-left party that presented itself as more in favour of an understanding among the left-wing parties (including the PS) than the BE had been until the 2015 election campaign. Second, the Partido Democrático Republicano (Democratic Republican Party - PDR) was created in 2015 by Marinho Pinto, an MEP elected in 2014, with the support of the agrarian micro-party Partido da Terra (Earth Party - MPT) and drawing on popularity stemming from his frequent presence on daytime TV. In ideological terms, the party may be defined as centrist, populist and anti-establishment. Third, Pessoas-Animais-Natureza (People-Animals-Nature - PAN) is a small environmentalist party whose results in the 2011 legislative election granted it the right to receive a state subvention. ${ }^{7}$ This allowed the party to conduct an excellent campaign in 2015, aimed at targeting and mobilising its own electorate.

\section{Playing the campaign game in austerity's backyard: opinion polls, issues and party positions}

The two main political forces in the Portuguese spectrum (PS and PAF) were facing a close race. Soon after the 2014 European election, the PS experienced a fall in voting intentions (from around 36 to around 33 per cent). ${ }^{8}$ However, immediately after Costa replaced Seguro, PS voting intentions reached an average of 37 per cent. Concurrently, the incumbent PSD and CDS-PP were able to attract, on average, around 35 per cent of voting intentions, which means that there was a technical tie with the PS for most of 2015. Things started to change in late September, when voting intentions for the coalition reached almost 40 per cent, while the Socialists ended the campaign with an estimated result of 32 per cent.

These figures are understandable given the feeble signs of economic recovery witnessed in 2014 and their impact on public opinion. The October election would not be a rose garden for the incumbents, since in May 201589 per cent of Portuguese described the economic situation of the country as poor, and 54 per cent expressed a similar assessment of their household's financial situation. ${ }^{9}$ However, a survey conducted in May-June 2015 showed that 73 per cent of the sample assessed the government's record as good or very good, while only 53 per cent expressed similar positive assessments of the PS as the main opposition party (Belchior \& Correia 2015). Moreover, 48 per cent believed that the incumbent's management of the economy was better or much better than that of the PS cabinets between 2008 and 2011 (Belchior \& Correia 2015). The weak signs of recovery in 2014 were being reproduced in the quarterly accounts: positive GDP growth rates in the first two quarters of 2015 ( 0.5 and 0.4 per cent vis-à-vis the previous trimester) and an unemployment rate for April-June 2015 of 11.9 per cent, 1.4 points lower than in 2014.

As for the far left, after a disastrous result in the 2014 European election and a downward trend in its polling results (the estimated vote share in March 2015 was four per cent), in the second half of September the BE showed signs of recovery. Meanwhile, CDU was expected 
to get around nine per cent of the votes, little more than its customary result in first-order elections since 1991 (8-9 per cent). In terms of smaller/new parties, the polls estimated that L-TDA and PDR would receive around two per cent of the votes each.

While the news of the Syrian refugee crisis and the Greek election campaign were echoing in Portugal, the political parties devoted most of their time to the country's economic situation after four years of austerity policies. Political strategy was also a hot topic: various possible post-election scenarios were discussed in a context in which it was not clear whether the Socialists would win the election or come second to PAF, but in which none of these parties seemed to be able to secure a majority of MPs. The history of Portuguese democracy would suggest that one of these two parties would support a minority government headed by the other. However, the specific context of the 2015 election - namely the austerity record of the PSD and CDS-PP cabinet and a newfound openness from left-wing political elites towards collaboration - made several other scenarios plausible, including an understanding between the Socialists and the far left. In early 2015, only L-TDA maintained that the extreme left should be open to forming a coalition with the Socialists under pro-European stances, in order to defeat the forces of austerity. CDU and BE initially discarded this idea, but in the weeks preceding election day it became attractive in their leaders' eyes. In a debate between Catarina Martins and António Costa (17 September), Martins stated her availability to reach an understanding with the Socialists after the election, under certain conditions. At the same time, the Communists gave signs of being available to take governmental responsibilities - a true novelty in the Portuguese context.

During the campaign, the incumbents and the PS exchanged accusations about who was responsible for the bailout. The PAF strived to communicate that their measures had worked, since the country had achieved a clean exit from the adjustment programme, and some austerity measures could be consequently relaxed, though gradually, during a second mandate under their rule. Also, they stressed that the results achieved could be endangered if the Socialists, pictured as prone to overspending, got back in power. One of PAF's most important policy proposals was a reform of social security, an urgent matter in a country where the demographic situation is endangering the long-term sustainability of pension schemes.

At the same time, the PS tried - not always successfully - to detach itself from the second Sócrates cabinet (2009-11) and the Sócrates arrest scandal, as well as to be seen as a reliable alternative to the current government and the far left (in fact, their manifesto was entitled Alternativa de Confiança [Trustworthy alternative]). The party presented itself as deeply committed to the European project and goals (since PS was not Syriza, as Costa argued more than once) and both able and willing to turn the page of austerity by relaxing the painful measures approved in the previous term at a faster pace than that proposed by the incumbents. To the left, the BE, CDU and L-TDA called for the restructuring or renegotiation of the sovereign debt, highlighted the deep scars that austerity had left in Portuguese society and maintained that workers' rights and incomes should return to pre-bailout levels.

While Portugal's EU and eurozone membership were not hot topics during the campaign, they were a divisive issue for the far left (Table 1). CDU is the only blatantly Eurosceptic political force in parliament: according to the Communists and Greens the EU has harmed the country and Portugal should consider a scenario of eurozone exit. In turn, both BE and the relevant new players in the campaign (PAN, L/TDA, PDR) have mixed feelings about the EU. In general terms, these parties maintain that EU membership can be a good thing, but 
Table 1. Positions of the main Portuguese political parties regarding European membership and the euro in 2014-15.

\begin{tabular}{lll}
\hline Party/Coalition & $\begin{array}{l}\text { Position on EU membership (Is it a } \\
\text { good thing for Portugal?) }\end{array}$ & $\begin{array}{l}\text { Position on the euro (Should } \\
\text { Portugal leave the eurozone?) }\end{array}$ \\
\hline PAF (PSD and CDS-PP) & Agrees & Disagrees \\
PS & Agrees & Disagrees \\
CDU (PCP-PEV) & Disagrees & Agrees \\
BE & Mixed & Tends to disagree \\
PAN & Mixed & Disagrees \\
L-TDA & Mixed & Tends to disagree \\
PDR & Mixed & Tends to disagree \\
\hline
\end{tabular}

Sources: VAAs euandi (http://euandi.eu/); EUVOX 2014 (www.euvox2014.eu); Bússola Eleitoral (www.bussolaeleitoral.pt); Fernandes \& Santana-Pereira (2014).

Note: Since the PDR leader was the main candidate in the MPT's lists in the 2014 EP election, the PDR position also takes into account the positions on the EU and the euro expressed by the latter party in 2014.

that its current format has caused harm to Portugal (and other countries); therefore, European institutions need to be reformed and current agreements discussed. Also, most of these parties do not support leaving the euro, finding the solution to Portugal's current financial woes in debt restructuring, or a renegotiation of the eurozone rules. At the same time, both PS and PAF kept declaring that EU membership was (and had been) good for Portugal and that leaving the euro was not an option (Table 1).

A voting advice application (VAA) - Bússola Eleitoral 2015 - prepared by a team of political scientists from the University of Lisbon was aired in early September. On the basis of programmatic documents and other materials, the parties were placed in a political space shaped by two orthogonal dimensions: socioeconomic left vs. right (i.e. preferences about the state's role in the economy) and traditionalism/nationalism vs. libertarianism/ cosmopolitarianism (covering positions about lifestyle, environment and European integration). Interestingly enough, most parties were located in the left-libertarian/ cosmopolitan quadrant (even though PS was closer to the centre-left and the Communist positions were less libertarian than those of the new left), while the coalition PAF was depicted as centre-right and as more traditionalist/nationalist than libertarian/ cosmopolitarian. The PDR was placed almost at the intersection of these two dimensions.

Four issues discussed during the summer and analysed by the VAA warrant special attention. Should the sovereign debt be restructured? Was austerity necessary? Should government spending be cut in order to tackle the budgetary deficit problem? Did the implementation of the MoU harm the country? In most cases, there was a strong division between the incumbents and the smaller far-left parties (CDU, BE, L-TDA), while the PS often adopted a moderate stance (Figure 1). For instance, while the far-left parties declared that the sovereign debt could not be paid as it is and should be restructured, PAF strongly rejected this idea and the Socialists were open to debt restructuring if the process stemmed from a Europe-wide agreement. Also, whereas the extreme left absolutely rejected austerity, the Socialist position was less categorical. Meanwhile, PAF maintained that frugality and measures of austerity were still inevitable, albeit to a lesser extent than in previous years. Third, the far left completely agreed that the implementation of the MoU was deleterious for Portugal, while the Socialists were less vehement in their support of this assertion and the incumbents strongly rejected it. Lastly, the PS was aligned with PAF in defending the need to cut state spending in order to solve the budgetary deficit issue. In contrast, the far 


\section{Portugal's sovereign debt should be restructured}

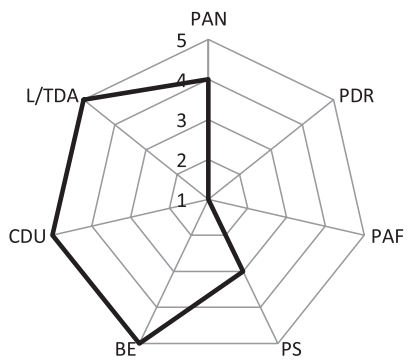

Troika's MoU was bad for Portugal

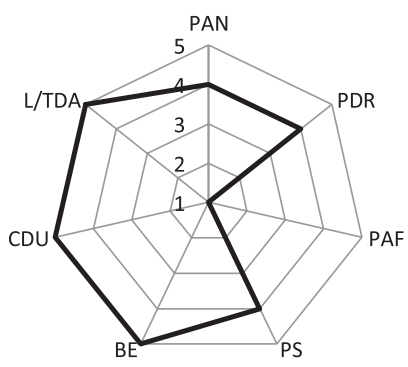

Austerity is Necessary

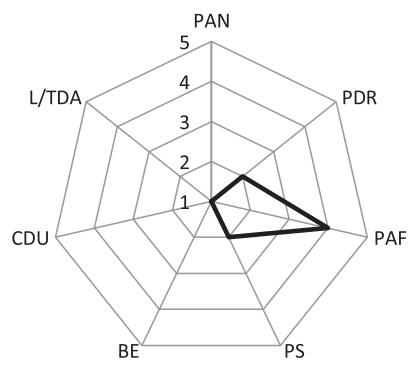

Cutting State spending is a good way to solve the budgetary deficit problem

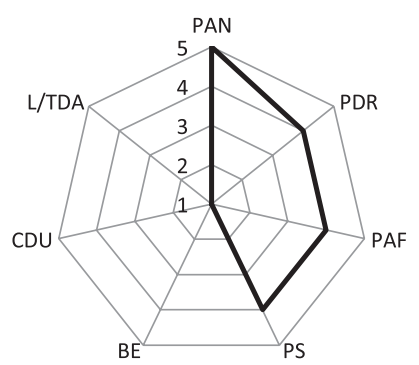

Figure 1. Positions of the main Portuguese parties on economic and financial issues. Source: Lobo, Santana-Pereira \& Sanches (2015).

Note: These graphs were built with data retrieved from the VAA Bússola Eleitoral 2015 (Electoral Compass 2015), designed by a team of political scientists from the Institute of Social Sciences, University of Lisbon. The VAA used data on party manifestos, party programmes, leader interviews to the press and other kinds of party-related content in order to compute party positions on several relevant topics. Each figure positions the parties according to their stances on a specific issue. Each circular grey line composing the spider web represents a position on a scale from 1 (party completely disagrees with the sentence) to 5 (party completely agrees with the sentence). Therefore, in general terms, the wider the polygon formed by the parties' positions (represented by a thick black line), the wider is the agreement regarding that specific sentence in the party system, and vice versa. Also, the more distant a party is from the centre of the spider web, the higher is its level of agreement with the sentence. For the sake of parsimony, we only include parties with parliamentary representation and micro parties that were relevant during and after the election campaign.

left absolutely rejected that the problem would be solved through cuts in government spending.

A final note on campaigning in the media is due. September was an intense month in political communication terms: several dyadic debates between the leaders of the main parties took place, as well as interviews and appearances on a political satire talk show. The most exciting debates were between Passos Coelho and Costa. The first (9 September) was broadcast live by the three generalist TV networks and watched by 3.4 million citizens (66 per cent of TV viewers that evening). ${ }^{10}$ The focus was on the past, namely on issues such as who was to blame for the bailout and the performance of the 2009-11 cabinet headed by Sócrates (who had just been moved from prison to house arrest). Costa was believed to have won this debate, ${ }^{11}$ which was also described as neither decisive nor enlightening. The second debate (17 September) was transmitted live on radio. This lengthier confrontation was heard by 1.2 million citizens (twice the average audience of the radio stations transmitting it) ${ }^{12}$ and this time the party leaders discussed their policy proposals more than past performance. The debate was deemed more informative than the first, and both political pundits and public opinion considered that Passos Coelho came out ahead. ${ }^{13}$ 


\section{The election results: first place, second place, who won in the end?}

The 2015 legislative election was not marked by an unequivocal victory of the governing coalition or by an absolute success of its main challenger, the PS. In very simplistic terms, one could argue that both political forces lost this election. Although the incumbents obtained the relative majority of votes, their 38.6 per cent vote share was considerably lower than their 2011 result and their parliamentary strength was substantially reduced (from 132 to 107 in a 230-seat chamber; Table 2). The coalition strategy benefited the PSD more than the CDS-PP: in fact, vis-à-vis the 2011-15 legislature, the current parliamentary groups are 25 per cent smaller in the case of CDS-PP but only 17 per cent smaller in the case of the PSD.

The PS came in second place, unable to capitalise on the negative impact of austerity on the government's popularity. Its vote share (32.3 per cent) was only slightly better than that of 2011 (when the party - then the incumbent - was severely punished), and it secured just 86 parliamentary seats (Table 2). On election night, the PAF leaders reacted to the results as a victory, while Costa took personal responsibility for the unsatisfactory figures but did not resign from the PS leadership.

The extreme-left parties with parliamentary representation had good results. The BE made a comeback by securing more than half a million votes, doubling its share of votes (from five to ten per cent) and electing 11 more MPs. It became the third party in Portugal, surpassing the CDU, whose result was only slightly better than in 2011, with 4,000 more votes and one additional seat in parliament (Tables 2 and 3 ). One of the most unexpected outcomes of this election was that L-TDA and PDR secured less than half of the vote shares estimated by the polls - 1.1 and 0.7 , respectively - while PAN was able to elect one MP in the electoral district of Lisbon (Table 2). The L-TDA result was even lower than that secured by the Maoist microparty Partido Comunista dos Trabalhadores Portugueses-Movimento Reorganizativo do Partido do Proletariado (Portuguese Workers' Communist Party-Reorganised Movement of the Party of the Proletariat - PCTP-MRPP). Interesting enough, among these parties, the one

Table 2. Official results of the 2015 and 2011 legislative elections in Portugal: vote shares and seats.

\begin{tabular}{|c|c|c|c|c|c|c|}
\hline & \multicolumn{2}{|c|}{2015} & \multicolumn{2}{|c|}{2011} & \multicolumn{2}{|c|}{ Differences (2015-11) } \\
\hline & Vote (\%) & Seats & Vote (\%) & Seats & Vote (\%) & Seats \\
\hline \multirow[t]{2}{*}{ PSD + CDS-PP } & 38.6 & 107 & 38.7 & 108 & -11.8 & -25 \\
\hline & & & 11.7 & 24 & & \\
\hline PS & 32.3 & 86 & 28.1 & 74 & +4.2 & +12 \\
\hline $\mathrm{BE}$ & 10.2 & 19 & 5.2 & 8 & +5 & +11 \\
\hline CDU (PCP-PEV) & 8.3 & 17 & 7.9 & 16 & +0.4 & +1 \\
\hline PAN & 1.4 & 1 & 1.0 & - & +0.4 & +1 \\
\hline PDR & 1.1 & - & - & - & - & - \\
\hline PCTP-MRPP & 1.1 & - & 1.1 & - & 0 & - \\
\hline L-TDA & 0.7 & - & - & - & - & - \\
\hline Others & 2.6 & - & 2.2 & - & +0.4 & \\
\hline Blank & 2.1 & - & 2.7 & - & -0.6 & - \\
\hline Null & 1.7 & - & 1.4 & - & +0.3 & - \\
\hline Total & 100 & 230 & 100 & 230 & - & - \\
\hline Turnout & 55.9 & - & 58.1 & - & -2.2 & - \\
\hline
\end{tabular}

Sources: Ministry of Internal Affairs (www.mai.pt).

Notes: In 2011 PSD and CDS-PP ran as separate parties; in 2015, they ran as the PAF coalition in mainland Portugal and the two electoral districts for national citizens living abroad (Europe and Rest of the World) but as separate parties in Madeira and Azores (where CDS-PP formed a coalition with the monarchist micro-party PPM [Partido Popular Monárquico People's Monarchist Party]). The figures for 2015 are the sums of the votes and seats gathered by both parties under these three electoral arrangements. 
that entered parliament (PAN) was the most unlikely to do so if one were to judge by the lack of media coverage and the popularity of its leader. This shortcoming was overcome via a very smart campaign based on online tools and aimed at securing the electoral support of its small but engaged electorate.

Never before in the history of Portuguese democracy had turnout in a legislative election been so low. The abstention rate was around 44 per cent (vis-à-vis 42 per cent in 2011), i.e. almost half of the registered voters. The official abstention figure may be partly attributed to the fact that the economic crisis had led to an indeterminate but presumably high number of national citizens leaving the country. While some may not have registered in their new electoral district and thus increased the abstention figures in their former district, others experienced difficulties in voting abroad. ${ }^{14}$ Some observers claim that there may be almost 900,000 'phantom voters' (registered but unable to vote in their constituency because they are deceased or registered twice because they had registered to vote elsewhere after having moved to a new district). In fact, in 2014 the estimated resident adult population was 8.8 million, while the electoral roll for 2015 included 9.7 million citizens. The removal of these phantom voters would lower the abstention rate to 38 per cent ${ }^{15}$ - still overwhelmingly high.

Using abstention as an indicator of exit and vote for the far-left or extra-parliamentary parties as signs of voice (Hirschman 1970), we could argue that in 2015 the number of Portuguese citizens opting for exit (i.e. abstaining) was overwhelming (more than four million) and higher than in 2011 (+239,000), while those opting for voice constituted a smaller group (1.37 million), although again slightly bigger than in 2011 (980,000). This rise in voters opting to exert their voice is due to the increase in voting both for the established far left and for extra-parliamentary parties (Table 3).

Broadly speaking, these election results represent a shift to the left in Portugal. The leftwing parties PS, BE and CDU secured 54 per cent of the seats in parliament, vis-à-vis 44 per cent in the previous legislature. They also represent a trend towards a smaller electoral weight of parties with governmental experience (PSD, CDS-PP and PS). In fact, those three parties taken together secured only 71 per cent of the votes, the lowest figure since 1985 and the third lowest in four decades of legislative elections in Portugal. Just four years earlier, they

Table 3. Vote distribution in the 2015 and 2011 legislative elections in Portugal (in thousands).

\begin{tabular}{lccc}
\hline & 2015 & 2011 & Differences (2015-11) \\
\hline PSD + CDS-PP & 2,086 & 2,160 & -728 \\
PS & 1,748 & 654 & +180 \\
BE & 551 & 1,568 & +262 \\
CDU(PCP-PEV) & 446 & 289 & +4 \\
Total parliamentary & 4,831 & 442 & -282 \\
PAN & 75 & 5,113 & +17 \\
PDR & 62 & 58 & +62 \\
PCTP-MRPP & 60 & - & -3 \\
L-TDA & 39 & 63 & +39 \\
Others & 139 & - & +12 \\
Total extra-parliamentary & 375 & 127 & +127 \\
Blank & 113 & 248 & -35 \\
Null & 90 & 148 & +10 \\
Turnout & 5,409 & 80 & -180 \\
Registered Voters & 9,683 & 5,589 & +59 \\
\hline
\end{tabular}

Source: Ministry of Internal Affairs (www.mai.pt).

Note: The figures are rounded. See also Table 2's notes. 
gathered more than 78 per cent of the votes. This phenomenon is linked to the exponential electoral growth of the BE and an increase in extra-parliamentary party voting (from 4.3 per cent in 2011 to 6.9 per cent in 2015) (Tables 2 and 3). This growth allowed a new political party (PAN) to enter parliament.

In spite of these minor shifts, the election results offer additional evidence of the Portuguese party system's resilience, which was already a distinctive feature of the country in the subset of crisis-stricken and/or bailed-out European peripheral democracies (Bosco \& Verney 2012): the main parties not only survived the severe economic crisis and the bailout but also the hard austerity measures implemented thereafter. Although they had disappointing results at the polls, none of the parties that signed the bailout agreement suffered overwhelming losses in electoral support vis-à-vis 2011, including the incumbents that had implemented austerity measures in the preceding four years.

\section{The long(est) process of government formation}

Given these election results, numerous post-electoral scenarios, some of them completely new, were possible. In fact, on the one hand, a coalition had never governed without an absolute majority in parliament; on the other, the PS had never formed a government with the parties on its left. The aftermath of the election constituted a brand new scenario in Portuguese politics in which the President of the Republic, Cavaco Silva, played a crucial role. Indeed, due to the semi-presidential nature of the Portuguese political system, the decision of whom to appoint as PM in light of the election results and after meeting all parliamentary groups lies with the president (for a description of the formal rules surrounding government formation in Portugal, see Fernandes [2016]). Moreover, due to the specific timetable of this legislative election and the following presidential election (scheduled to occur in January 2016), a new electoral contest (which was believed to be Cavaco's favourite solution if the PAF government were to be rejected by parliament) could not be called before the spring of 2016.

A few days after the election, it became clear that an agreement between PAF and the PS in support of a minority government led by Passos Coelho was unlikely. However, an agreement between the Socialists and the far-left parties allowing the formation of a minority government headed by Costa had been only superficially mentioned by the smaller parties in September and had never been on the party agendas before the campaign. In spite of that, after a series of meetings with the PAF leaders, as well as consultations with the far-left parties, Costa decided not to support or participate in a government headed by PAF. Some observers interpreted this as due to fear of the same fate as the Greek socialist PASOK

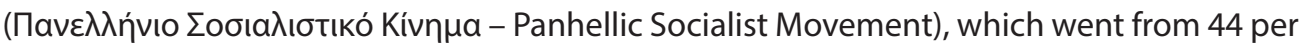
cent of votes in 2009 to less than five per cent in 2015 (Teperoglou, Tsatsanis \& Nicolacopoulos

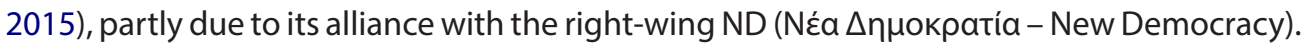
Others believed Costa wanted to become PM and would not accept an agreement granting Passos Coelho a second mandate if there was a chance of becoming head of government with the support of the far left.

On 22 October, in a controversial speech to the nation depicting a left-wing government as a dangerous option for the country, the President announced he would nominate Passos Coelho as formateur, despite the evident lack of majority and a high chance that the leftwing parties would vote down the government in parliament at the first opportunity. Some 
saw the presidential speech as encouraging Socialist MPs to oppose their leader and support a second PAF cabinet. There were indeed voices of dissent within the PS, mainly from a few party members who were close to the previous secretary general. However, in mid-November, just 11 days after its formation, the new PAF government fell following a motion of censure voted for by all the left-wing parties, with no dissent within the PS parliamentary group. The right-wing coalition would eventually be dissolved a few days before Christmas; ten days later, Portas announced that he would not run for an additional mandate as CDS-PP leader.

In the days that followed the PAF government's rejection, Costa waited for the President to designate him as PM but Cavaco Silva called a series of meetings with the heads of business associations and trade unions before taking a decision. On 24 November 2015, the President finally appointed Costa, once he had clarified some aspects of his agreements with BE and CDU. Costa thus became the first PM in four decades of democracy to rule with the support of the far left. The PS government programme, revised under the agreement with the far left, includes restoring public sector wage cuts, increasing social benefits and lowering taxes on families and small/medium-size companies, and renegotiating the privatisation of public companies such as the national airline, TAP Portugal. Although, initially, financial markets and rating agencies had feared that such a programme would threaten the country's growth, jobs and fiscal stability, in the days surrounding Costa's appointment the markets actually reacted positively.

The Portuguese arrangements stemming from the 2015 election are close to the idealtype of 'contract parliamentarism', where minority governments formally develop institutionalised relationships with their support parties to an extent that they come close to being majority governments, and the agreement with the parties outside the cabinet is explicit, written, publicly available and formalises more than a short-term or issue-focused understanding (Aylott \& Bergman 2004; Bale \& Bergman 2006). ${ }^{16}$

\section{Conclusions}

The October 2015 legislative election was the first to take place in Portugal after the adjustment programme resulting from the 2011 bailout came to an end (spring 2014), although austerity continued. Several aspects of the election results are remarkable. First, as in 2011 , the party system remained quite stable, with only a small decrease in the number of votes gathered by the mainstream parties and the entry to parliament of one new party - not anti-establishment and electing just one MP. As mentioned above, the explanation for the fact that no new anti-system forces gained considerable electoral relevance, as in Italy and Spain (but not Ireland), may be that protests were mainly and successfully channelled through the far-left parties, i.e. political actors in parliament since 1975 (PCP) and 1999 (BE). Furthermore, the absence of a'protest entrepreneur'from outside the traditional parties and able to guide an anti-establishment protest that would go beyond the single mobilisations was another relevant factor that may explain the difference between Portugal and its Southern European neighbours. Second, the incumbent coalition responsible for the implementation of austerity measures under the 2011-14 adjustment programme was the most voted-for political force, while the main challenger PS came second and the far left had a significant but not overwhelming increase in its vote shares. We believe that the incumbent coalition may have been successful in convincing a considerable share of the Portuguese electorate that austerity worked and that the economic situation was improving; 
the PS and its leader were perhaps unable to persuade enough voters that they were a reliable alternative, especially given their responsibility for the 2011 bailout request; lastly, some of the Portuguese electorate may have preferred to force the left to reach an agreement instead of giving carte blanche to the PS alone. Third, this election led to the first PS minority government with the support of the far left in parliament - the first in four decades of democratically appointed governments.

However, the significance of the 2015 legislative election goes way beyond Portugal's borders. After all, this was the first of a series of three general elections taking place in European crisis-stricken countries after an adjustment programme had ended without the need of a second adjustment programme: Portugal in October 2015, Spain in December 2015 and Ireland in February 2016. These elections are different from the Greek elections of January and September 2015, since the Greek bailout continues. Ireland's economic adjustment programme and Spain's support package for bank recapitalisation were both completed in 2013. Interesting enough, in both the Spanish and the Irish elections, the results are somewhat similar to those of the Portuguese election: the right-wing incumbent was the most voted-for political force, but was unable to secure a majority of the seats in parliament, while the main opposition party was not sufficiently rewarded (Ireland) or rewarded at all (Spain). In Spain, indeed, a Portuguese-style arrangement in terms of government formation was actually discussed between the Spanish Socialists and Podemos, but, was never implemented and new elections were scheduled to take place in June 2016.

One of the main lessons to be learnt from the Portuguese election is that incumbents who implement austerity policies under an adjustment programme ending with a clean exit will not necessarily be severely punished at the polls: rather, all parties that have shared government responsibilities in the last few years will be penalised (if in power) or not sufficiently rewarded (if in opposition) by the electorate. The crisis, in short, seems to have deepened the gap between parties 'who govern' and parties 'who represent' (Mair 2011), so that mainstream opposition parties may need to coalesce with other (sometimes new) political forces in order to propose a credible and stable government alternative and turn the page on austerity.

\section{Notes}

1. Elisabetta De Giorgi is particularly responsible for the first two sections, José Santana-Pereira for the third and fourth sections, while the introduction, conclusions and fifth section are the result of joint work.

2. Title retrieved from the British Telegraph, 5 October 2015. The Spanish EI Pais, Italian La Repubblica and American New York Times used similar wordings in their depiction of the election results.

3. March (2008) describes the BE as a radical-left party and PCP as an extreme-left party; for the sake of parsimony we use the terms 'far left' or 'extreme left' when referring to these two parties collectively.

4. Data available from Eurostat (http://ec.europa.eu/eurostat).

5. Standard Eurobarometers 76 and 83 . These data are available at: http://ec.europa.eu/public_ opinion/archives/eb_arch_en.htm

6. R. Gaudêncio \& M. J. Lopes, 'O mundo gira, ele resiste. Mas não serà sempre assim', Publico, 6 September 2015, available online at: http://www.publico.pt/politica/noticia/o-mundo-giraele-resiste-isto-nao-sera-sempre-assim-1,706,839

7. According to Law 19/2003, article 5, point 7, regarding party and campaign financing, in legislative elections parties that are not able to elect representatives but nevertheless gather 
more than 50,000 votes may request state subventions. This was the case of PAN in 2011 (around 58,000 votes).

8. The poll analysis is based on the data made available by the research project Public Opinion and Sentiment Tracking, Analysis, and Research (POPSTAR), which aggregates and computes estimations of voting intentions based on all the opinion polls published by the media in Portugal. The data are available in the project's website: www.popstar.pt.

9. Standard Eurobarometer 83. These data are available at: http://ec.europa.eu/public_opinion/ archives/eb_arch_en.htm.

10. 'Debate televisivo entre Passos e Costa com audiência histórica de 3,4 milhões', Expresso, 10 September 2015, available online at: http://expresso.sapo.pt/politica/2015-09-10-Debatetelevisivo-entre-Passos-e-Costa-com-audiencia-historica-de-34-milhoes

11. Two opinion polls were conducted after the debate by polling companies Aximage and Eurosondagem. Both display the same pattern: the proportion of respondents who consider that António Costa won the debate is greater than that of respondents who claim that Passos Coelho had a better performance.

12. 'Histórico: debate Passos/Costa na rádio ouvido por quase 1,3 milhões', Expresso, 18 September 2015, available online at: http://expresso.sapo.pt/politica/2015-09-18-Historico-debate-PassosCosta-na-radio-ouvido-por-quase-13-milhoes

13. '8 análises ao debate Passos-Costa', Observador, 17 September 2015, available online at: http:// observador.pt/2015/09/17/8-analises-ao-debate-passos-costa/ In terms of public opinion, a poll conducted in the aftermath of the debate reports the following findings: 43 per cent of the respondents believed that Passos Coelho won the debate, against 30 per cent who preferred Costa's performance. The poll was carried out by Marktest and is available at the ERC (Entidade Reguladora para a Comunicação Social - Media Regulatory Authority) website (www.erc.pt).

14. 'Petição visa facilitar recenseamento e participação eleitoral de portugueses no estrangeiro', Lusa, 22 November 2015, available online at: http://www.sapo.pt/noticias/peticao-visa-facilitarrecenseamento-e_565198bf5c2b514f62186ec4

15. Data provided by IDEA, 4 December 2015, available online at: http://www.idea.int/vt/ countryview.cfm?id=184.

16. The agreements between the PS and the other parties, signed on 10 November 2015, are available online: Agreement PS/BE (http://www.ps.pt/images/imprensa/comunicados ps/20151110_PS_BE.pdf); Agreement PS/PCP - the main coalition partner of CDU (http:// www.ps.pt/images/imprensa/comunicados_ps/20151110_PS_PCP.pdf); Agreement PS/ PEV - the other member of the CDU coalition (http://www.osverdes.pt/media/Parlamento/ PosicaoConjuntaPS_PEV.pdf).

\section{Disclosure statement}

No potential conflict of interest was reported by the authors.

\section{Funding}

This work was supported by Portuguese National Funds through the Fundação para a Ciência e a Tecnologia (FCT) within the project 'UID/CPO/04627/2013'.

\section{Notes on contributors}

Elisabetta De Giorgi is a post-doctoral research fellow at the Portuguese Institute of International Relations (IPRI) of the NOVA University of Lisbon (UNL). Her main research interests are parliaments from a comparative perspective, political parties and party systems. She has published in national and international journals such as Acta Politica, Journal of Legislative Studies, Journal of Modern Italian Studies, Revue Internationale de Politique Comparée, and Italian Political Science Review, among others. 
José Santana-Pereira (PhD in political and social sciences, European University Institute, Florence, 2012), is a post-doctoral research fellow at the Institute of Social Sciences (ICS), University of Lisbon. His research interests comprise elections, public opinion, political attitudes and behaviour, media and politics, and the organisation and effects of political campaigns. His work has been published in journals such as Electoral Studies and South European Society and Politics.

\section{References}

Accornero, G. \& Pinto, P. R. (2015) “'Mild mannered"? Protest and mobilisation in Portugal under austerity, 2010-2013', West European Politics, vol. 38, no. 3, pp. 491-515.

Afonso, A. (2015) 'Why the next Portuguese election will not see the surge of a left-wing challenger like Podemos or Syriza', available online at: http://blogs.lse.ac.uk/europpblog/2015/08/25/why-thenext-portuguese-election-will-not-see-the-surge-of-a-left-wing-challenger-like-podemos-or-syriza/

Aylott, N. \& Bergman, T. (2004) 'Almost in government, but not quite: the Swedish Greens, bargaining constraints and the rise of contract parliamentarism', paper presented at the ECPR Joint Sessions, Uppsala, 13-18 April.

Bale, T. \& Bergman, T. (2006) 'Captives no longer, but servants still? Contract parliamentarism and the new minority governance in Sweden and New Zealand', Government and Opposition, vol. 41, no. 3, pp. 422-449.

Baumgarten, B. (2013) 'Geração à rasca and beyond: Mobilizations in Portugal after 12 March 2011', Current Sociology, vol. 61, no. 4, pp. 457-473.

Belchior, A. \& Correia, A. (2015) Panel Survey to the Portuguese population - First and Second Waves, Project 'Public Preferences and Policy Decision-Making. A Longitudinal and Comparative Analysis', PTDC/IVCCPO/3921/2012, CIES-IUL and ISCTE -IUL, Instituto Universitário de Lisboa, Lisbon.

Borghetto, E., De Giorgi, E. \& Lisi, M. (2014) 'Government failure, opposition success? Electoral performance in Portugal and Italy at the time of the crisis', Jean Monnet Occasional Papers, No. 5 Institute for European Studies (Malta).

Bosco, A. \& Verney, S. (2012) 'Electoral epidemic: the political cost of economic crisis in Southern Europe, 2010-2011', South European Society and Politics, vol. 17, no. 2, pp. 129-154.

De Giorgi, E. \& Moury, C. (2015) 'Introduction: Conflict and consensus in parliament during the economic crisis', The Journal of Legislative Studies, vol. 21, no. 1, pp. 1-13.

De Giorgi, E., Moury, C. \& Ruivo, J.P. (2015)'Incumbents, opposition and international lenders: governing portugal in times of crisis', The Journal of Legislative Studies, vol. 21, no. 1, pp. 54-74.

De Giorgi, E. \& Russo, F. (2015) 'The opposition parties' behaviour in Portugal between internal and external challenges', paper presented at the 22nd International Conference of Europeanists, Paris, 8-10 July.

Fernandes, J. M. (2016) 'The seeds for party system change? The 2015 Portuguese general election', West European Politics, vol. 39, no. 4, pp. 890-900.

Fernandes, J. M. \& Santana-Pereira, J. (2014) ‘Os programas eleitorais das europeias de 2014: Uma análise preliminar das principais dimensões de competição', RI: Relações Internacionais, no. 41, pp. 81-95.

Freire, A. (2015) 'The condition of Portuguese democracy during the Troika's intervention, 2011-2014: government-opposition, regime support and political trust', paper presented at the 9th ECPR General Conference, Montreal, 26-29 August.

Freire, A. \& Santana-Pereira, J. (2012) 'Portugal, 2011: the victory of the neoliberal left, the defeat of the left', Portuguese Journal of Social Sciences, vol. 11, no. 2, pp. 179-187.

Freire, A. \& Santana-Pereira, J. (2015) 'More second-order than ever? The 2014 European election in Portugal', South European Society and Politics, vol. 20, no. 3, pp. 381-401.

Hirschman, A. O. (1970) Exit, Voice, and Loyalty: Responses to Decline in Firms, Organizations, and States, Harvard University Press, Cambridge (MA).

Jalali, C. (2014) 'For whom the bailout tolls? The implications of the 2013 local elections for the Portuguese party system', South European Society and Politics, vol. 19, no. 2, pp. 235-255.

Ladi, S. (2014) 'Austerity politics and administrative reform: the Eurozone crisis and its impact upon Greek public administration', Comparative European Politics, vol. 12, no. 2, pp. 184-208. 
Lijphart, A. (2012) Patterns of Democracy, Yale University Press, New Haven, CT.

Lobo, M. C., Santana-Pereira, J. \& Sanches, E. (2015) ‘Relatório síntese da Bússola Eleitoral, 2: A política económica vista pelos eleitores', available online at: http://marinacostalobo.pt/webwp/wp-content/ uploads/2014/11/relat\%C3\%B3rio-02-da-Bussola-Eleitoral1.pdf

March, L. (2008) Contemporary Far Left Parties in Europe: From Marxism to the Mainstream, Friedrich Ebert Stiftung, Bonn/Berlin.

Magalhães, P. (2012) 'After the bailout: responsibility, policy, and valence in the Portuguese legislative election of june 2011', South European Society and Politics, vol. 17, no. 2, pp. 309-327.

Mair, P. (2011) 'Bini Smaghi vs. the parties: representative government and institutional constraints, robert schuman centre for advanced studies and eu democracy observatory', EUI working paper no. 2011/22 European University Institute, Florence.

Martín, I. \& Urquizu-Sancho, I. (2012) 'The 2011 general election in Spain: the collapse of the socialist party', South European Society and Politics, vol. 17, no. 2, pp. 347-363.

Moury, C. \& Freire, A. (2013) 'Austerity policies and politics: the case of Portugal', Pôle Sud, vol. 2, 35-56.

Sacchi, S. (2015) 'Conditionality by other means: EU involvement in Italy's structural reforms in the sovereign debt crisis', Comparative European Politics, vol. 13, no. 1, pp. 77-92.

Teixeira, C., Tsatsanis, E. \& Belchior, A. (2014) 'Support for democracy in times of crisis: diffuse and specific regime support in Portugal and Greece', South European Society and Politics, vol. 19, no. 4, pp. 501-518.

Teperoglou, E., Tsatsanis, E. \& Nicolacopoulos, E. (2015) 'Habituating to the new normal in a postearthquake party system: the 2014 European election in Greece', South European Society and Politics, vol. 20, no. 3, pp. 333-355.

Tsatsanis, E. \& Teperoglou, E. (2014) ‘Dealignment, de-legitimation and the implosion of the two-party system in Greece: the earthquake election of 6 May 2012', Journal of Elections, Public Opinion and Parties, vol. 24, no. 2, pp. 222-242. 